\title{
Nova akademska slovnica knjižne češčine
}

\author{
Petra Stankovska
}

Cobiss: 1.19

František Štícha idr., Akademická gramatika spisovné češtiny, Praha: Academia 2013, 974 str.

Novo, Akademsko slovnico knjižne češčine je šest avtorjev (František Štícha, Miloslav Vondráček, Ivana Kolářová, Jana Hoffmannová, Jana Bílková in Ivana Svobodová) izoblikovalo pod vodstvom in koordinacijo Františka Štíche z Inštituta za češki jezik Češke akademije znanosti (Ústav projazyk český Akademie věd České republiky). Delo je bilo od začetka zasnovano kot »kratek« opis sodobne knjižne češčine (str. 9), ki bi mu sledila večdelna slovnica knjižnega jezika, v kateri bodo temeljne razlage izhajale iz podatkov, zbranih $\mathrm{v}$ nacionalnem korpusu češkega jezika (Český národní korpus), in katere prvi del je že v pripravi.

Enodelna akademska slovnica knjižne češčine je namenjena kulturni javnosti in je po nekaj letih prva tovrstna publikacija, ki hoče »ponuditi urejen sistem temeljnih informacij o pojavih in naravnih pravilih sodobne slovnice češčine, zlasti v njeni pisani obliki« (str. 15), pri čemer se poleg opisa trenutnega stanja jezika ne izogiba »priporočanju ali odsvetovanju uporabe takšnega ali drugačnega izraza«, kar se pa nikakor ne sme dojemati kot »preskriptivno dejanje« (str. 17). Kot pove že naslov, se slovnica ukvarja z opisom knjižne češčine in tako ostanejo neknjižni jezikovni pojavi večinoma ob strani, čeprav se izjemoma, pogosto $\mathrm{v}$ mejnih primerih, v slovnici tudi pojavijo. Glede na namen in ciljne uporabnike je s tem delom delno primerljiva npr. Priročna slovnica češkega jezika (Příruční mluvnice češtiny, ur. Petr Karlík - Marek Nekula - Zdenka Rusínová, Praha: Nakladatelství Lidové noviny, 1995 - v nadaljevanju PMČ), ki večinoma sledi tradicionalnemu pristopu k opisu slovnice, vendar v nekaterih poglavjih odslikava najnovejše pojave v jeziku, poleg tega pa iz opisa ne izključuje substandardnih jezikovnih pojavov, čeprav večina razlag zadeva knjižni jezik. Nova akademska slovnica poleg drugih značilnosti prinaša rezultate uporabe pojava sodobnega jezikoslovja - korpusa. Gre za prvo slovnico, osredotočeno na opis češkega knjižnega jezika, ki črpa in tudi navaja primere iz korpusa, ${ }^{1}$ prav tako tudi pri opisu in razlagah izhaja iz korpusnih

1 Na korpusnih podatkih temelji tudi opis češke slovnice Václava Cvrčka (Václav Cvrček idr., Mluvnice současné češtiny 1: jak se piše a jak se mluví, Praha: Karolinum, 2010), ki pa zajema v svoje razlage v veliki meri tudi neknjižne oblike češčine, zlasti t. i. splošnega pogovornega jezika (obecná čeština), ki se uporablja pretežno v govorjeni komunikaciji. 
podatkov. To je izjemno pomembno, saj prav impozantna količina podatkov, ki jih pred vpeljavo korpusnih raziskav ni bilo mogoče zbrati, razvrstiti in obdelati, omogoča avtorjem bolj celovit, razširjen in najbrž tudi bolj objektiven pogled na sodobni češki jezik.

Po uvodu sledi slovnična snov, ki je konceptualno zelo dobro razdeljena $\mathrm{v}$ pet jasno opredeljenih vsebinskih sklopov, ki služijo svojemu namenu - ponuditi temeljne razlage o jezikovnem sistemu češčine. Vsak sklop je označen z rimsko številko, in ta oznaka je vidna tudi na robu vsake strani, kar je zelo priročno: I. Uvod; II. O jeziku, govoru in komunikaciji (O jazyku, reči a komunikaci - str. 23-78); III. Slovnica besede (Gramatika slova - str. 79-540); IV. Slovnica stavka (Gramatika věty - str. 541-788); V. Slovnica zveze stavkov (Gramatika souvětí - str. 789-886); VI. Slovnica besedila (Gramatika textu - str. 887-940). Termin slovnica (oz. gramatika) je razumljivo razložen v prvem poglavju uvodnega sklopa kot »sistem jezikovnih pravil, ki so nastala naravno in so se razvila med naravnim, spontanim procesom komunikacije« (str. 14). Temu sledi še navedba sklopov slovnice, ki so obdelani v pričujočem priročniku: besedotvorje in oblikoslovje (III. sklop), skladnja stavka (IV. sklop) in zveze stavkov (V. sklop) ter nadstavčna oz. besedilna skladnja (VI. sklop). Iz naštetega je razvidno, da avtorji v delo niso vključili tradicionalnega slovničnega poglavja o glasoslovju (ki ga najdemo v slovnicah Mluvnice češtiny 1-3, ur. Jan Petr, Praha: Academia, 1986-1987 - v nadaljevanju MČ - ali Př́ruční mluvnice češtiny, 1995). Namesto tega so najbrž iz praktičnih razlogov na začetek priročnika (II. sklop, str. 34-75) umestili izbrana poglavja o pravopisu besed, rabi velikih in malih črk, vejic in ločil na splošno, kar je bilo tudi del starejših slovnic, namenjenih širokemu krogu uporabnikov (npr. Bohuslav Havránek - Alois Jedlička, Česká mluvnice, Praha: Státní pedagogické nakladatelství, 1959). Pomembno in poučno je tudi poglavje o pojmovanju jezika in komunikacije, ki na kratko in jedrnato razlaga temeljne termine, ki se uporabljajo pri raziskovanju, opisu in razlagah sistemskih pojavov v jeziku, kot so npr. zvrsti češkega jezika, raba, norma, kodifikacija, sintagmatika, paradigmatika idr. (str. 23-33). V primerjavi s PMČ manjkajo specializirana poglavja o leksikologiji in stilistiki, ki pa s stališča pojasnjenega pojmovanja slovnice oz. njenega funkcioniranja dejansko ne spadajo med cilje opisa jezikovnega sistema, ki so si jih zastavili avtorji tega priročnika. Kljub temu leksikološke in stilistične razlage niso povsem izvzete, saj se pojavljajo na več mestih slovnice ob različnih drugih temah. Tako se na primer na str. $381 \mathrm{v}$ poglavju o pridevnikih srečamo z razlago »slovnično-leksikalne veljavnosti/vrednosti pozitiva«, ki pa od uporabnika zahteva že določeno raven poznavanja in razumevanja leksikoloških teorij.

Najobsežnejši, III. sklop (več kot 450 strani) je sestavljen iz treh delov: o lastnostih besed, o besedotvorju in oblikoslovju. Prvi del (Vlastnosti slova a slovní druhy, str. 79-89) na kratko opisuje besedo oz. leksem in razvrščanje v besedne vrste ter uvaja za češke slovnice nekoliko nenavaden sistem delitve besed $v$ le osem besednih vrst (v zaporedju: samostalnik, pridevnik, prislov, glagol, predlog, veznik,

V primerjavi s Štíchovo akademsko slovnico tako prinaša opis sistema substandardne češčine kontrastivno s knjižnimi oblikami. 
členek in medmet), saj tradicionalni besedni vrsti zaimek in števnik pridružuje drugim besednim vrstam $\mathrm{z}$ argumentom, da je opredelitev teh dveh besednih vrst problematična, da gre za neosnovni besedni vrsti (nezákladni slovni druhy, med katere se uvrščajo še vezniki, predlogi, členki in medmeti, kar je podrobno opisano že v MČ 2, str. 13-26) in da se tudi znotraj teh dveh vrst nahajajo oblikoslovno precej raznovrstne besede. Ideja razporeditve zaimkov in števnikov v različne druge osnovne besedne vrste (základni slovni druhy) sicer ni nelogična in se npr. uveljavlja tudi v slovenski slovnici (Jože Toporišič, Slovenska slovnica, Maribor: Obzorja, ${ }^{4} 2004$, str. 255-256), vendar je v tem priročniku problematična zato, ker se pojavlja le $\mathrm{v}$ tem podpoglavju, medtem ko je $\mathrm{v}$ preostalih razlagah praktično neuporab(lje) na. Tako se v tretjem delu tega sklopa (Slovni druhy a jejich morfologie, str. 288535), ki je namenjen oblikoslovnim razlagam, avtorji vračajo $h$ klasičnemu češkemu modelu desetih besednih vrst ( $\mathrm{v}$ tradicionalnem zaporedju: samostalnik, pridevnik, zaimek, števnik, glagol, prislov, predlog, veznik, členek, medmet), torej vključno z zaimki in števniki kot posebnima besednima vrstama. To pomeni, da je vprašanje razvrščanja besed $\mathrm{v}$ besedne vrste metodološko nekoliko nedodelano, težave pa ne odpravlja niti razlaga na začetku poglavja o sklanjanju zaimkov (in podobna razlaga na začetku poglavja o števnikih na strani 417), ki zaimke označuje kot »morfološko in skladenjsko zelo nespecifično besedno vrsto«, vendar pa jo kot takšno opisuje v samostojnem poglavju zaradi tradicije in tudi zato, ker »je tudi pri tej skupini besed mogoče najti zelo osnovno skupno funkcijo - kazalno oz. nakazovalno funkcijo in funkcijo nadomeščanja (str. 389). Na koncu je torej tudi del o češkem oblikoslovju zastavljen precej tradicionalno, tako kot $\mathrm{v}$ drugih vsaj delno primerljivih slovnicah (npr. MČ, PMČ). V nasprotju z njimi pa tu obravnavana akademska slovnica uvršča stopnjevanje pridevnikov in prislovov $\mathrm{v}$ oblikoslovni del, čeprav gre za tradicionalno pojmovano besedotvorno kategorijo - tako v MČ kot v PMČ je obravnavano v poglavjih o besedotvorju. Uvrstitve stopnjevanja v oblikoslovni del priročnik posebej ne komentira, razen s kratko, dejansko brezvsebinsko in predvsem neargumentirano izjavo, da »stopnjevanje pridevnikov razumemo kot slovnični pojav (in stopnjo kot slovnično kategorijo, ki je tipična za pridevnike in prislove, četudi ne za vse)«(str. 380). Ravno opis tega pojava znotraj oblikoslovnega poglavja je morda razlog za precej nedoločeno in površno razlago o oblikah primernika, ki ga $\mathrm{v}$ češčini načeloma tvorimo na tri zelo različne načine: $\mathrm{s}$ pomočjo pripon -ejšil/-ějš́ (nový - novějšì) ali -ší (prudký - prudši ), pri nekaterih pridevnikih pa z dodajanjem končnice $-i$ ob spremembi končaja podstave (hezký - hezči). Glede na to, da slovnica uporablja korpusne podatke, bi lahko ravno v tem poglavju bistveno prispevala $\mathrm{k}$ opisu in morda priporočanju stilistične razmejitve oblik primernika, ki se v sodobni češčini pri nekaterih pridevnikih poleg oblike, tvorjene s $-\check{s} i$ ali $-i$, pojavlja tudi s pripono -ejš́l-ějš́s (npr. pridevnik snadný ima lahko primernik snazš́ ali snadnějši $)$. Namesto pregledne analize in opisa formalnih oblik pa se avtorji bolj posvečajo pomensko-funkcijskemu opisu teh oblik (str. 380-385).

Korpusni podatki so ustrezno uporabljeni npr. pri opisu dvojničnih oblik končnic mestnika $(-u /-e(/-\grave{e}) \mathrm{v}$ ednini in po velarnem končaju podstave -ích/-ách v množini) pri moški trdi neživi (vzorec hrad) in srednji trdi sklanjatvi (vzorec město), čeprav ne dosega izčrpnosti pri naštevanju oblik, kakršna je značilna za 
podobno poglavje v MČ. Podobno velja za opis glagolskih oblik, npr. uporabe in pomena zanikanega velelnika (str. 449-50), kjer slovnica ob primerih opozarja na pomenske razlike, nastale $\mathrm{s}$ spremembo vida zanikanega glagola $\mathrm{v}$ velelniku, ko uporaba nedovršnega glagola pomeni navadno sporočanje, poziv (Nedělej pořád tytéž chyby!), ob uporabi dovršnega glagola pa dobi poved dodaten pomen svarila (Neudělej zas tutéž chybu!). Zanimiv je tudi opis nihanja med oblikami trpnega deležnika $\mathrm{z}$ alternacijo končaja podstave in brez alternacije (podobno nihanje oblik v manjši meri obstaja tudi v slovenščini, npr. prenesen - prenešen), kjer slovnica dejansko prinaša statistične podatke o pogostnosti rabe različic pri posameznih besedah (npr. misen - mišen, mrazen - mražen, ohrazen - ohražen idr., str. 488), vendar jih ne komentira in tudi ne priporoča ustreznejše oblike (v nasprotju z izjavo iz uvodnih poglavij, da bo priročnik prinesel tudi priporočila za ustrezno rabo). Predlogi so v oblikoslovnem delu predstavljeni vedno s sklonom ali skloni, s katerim ali s katerimi se kombinirajo. Razpredelnica pregledno prinaša opis prislovnodoločilnega pomena, ki ga v kombinaciji s samostalnikom v danem predložnem sklonu lahko izražajo posamezni predlogi (str. 509-515).

Skladenjska problematika je obravnavana $\mathrm{v}$ treh preostalih sklopih. Največ prostora je namenjeno skladnji stavka (str. 541-786), manj medstavčni skladnji (str. 789-883), bolj informativno oziroma v obrisih pa so podani nekateri pojavi besedilne skladnje (str. 887-940). Sklop o skladnji stavka namreč kompleksno, z več vidikov obdela problematiko stavka kot »slovnično urejene osnovne enote besedila s funkcijo povedi/izreka«, ki jo je »nepotrebno in nemogoče jasno opredeliti, torej določiti njene meje« (str. 541). Različni pogledi na to enoto in njeno zgradbo so smiselno razdeljeni v posamezna poglavja: (1) Definicija stavka in stavčni odnosi (str. 541-550), (2) Besedni red in členitev po aktualnosti (str. 551-591), (3) Nelinearne stavčne strukture (str. 592-649), (4) Sinonimija stavčnih struktur (str. 650-655), (5) Modifikacija stavčnih struktur (str. 656-666), (6) Stavčni členi (str. 667-735), (7) Ujemanje (str. 736-746), (8) Stavki z zanikanjem (str. 747-754), (9) Komunikacijska vloga in modalnost stavka (str. 755-783). Nabor in razporeditev vsebin je tako podobna kot v najnovejši skladnji Miroslava Grepla in Petra Karlíka (Skladba češtiny, Olomouc: Votobia, 1998) v tem smislu, da klasične stavčne člene obravnava šele po poglavjih, namenjenih razlagi stavčnih struktur. V nasprotju z omenjeno skladnjo in tudi PMČ obravnavana Akademska slovnica ne uporablja razločevanja med temeljnima terminoma stavek (věta) in poved (výpověd') v smislu abstraktne, možne, slovnično pravilne enote, ki ni vpeta v konkretno komunikacijsko situacijo (= věta), in stavka, ki je uporabljen v določeni uresničeni komunikacijski situaciji (= výpovéd $).{ }^{2}$ Namesto tega v vseh pomenih uporablja klasična »šolska« termina věta in souvětí, kar upravičuje s tem, da sta to termina, dobro znana vsem potencialnim uporabnikom tega priročnika. Na določenih mestih pa uvaja v razlage še termin klauze (str. 542) v pomenu odvisnega stavka znotraj souvětí (= zveza stavkov, čemur ustreza slovenski termin večstavčna poved). Razmeroma veliko prostora je namenjeno razlagam nelinearnih stavčnih struktur, katerih manjši

2 Definiciji obeh terminov sta povzeti po knjigi Miroslava Grepla in Petra Karlíka Skladba češtiny, Olomouc: Votobia, 1998, str. 20-21. 
del vsebuje bolj teoretična pojasnila s pomočjo stavčnih vzorcev (str. 593-598), večji del pa je namenjen razlagam rabe nekaterih morfoloških sredstev zlasti $\mathrm{v}$ povedkovem položaju. Ravno te praktične razlage, opremljene $\mathrm{z}$ velikim številom primerov, pogosto črpanim iz Češkega nacionalnega korpusa, so zelo uporabne, pa naj bo to npr. del o uporabi pasivnih glagolskih oblik, ki je smiselno povezan z osnovnimi razlagami deagentizacije (str. 618-639), ali t. i. rezultativi (str. 639-648). $Z$ vidika praktične uporabe je še zlasti dobrodošla uvrstitev poglavij o sinonimiji in modifikaciji stavčnih struktur. Pri razlagah stavčnih členov se slovnica drži delitve na komplemente (obvezna dopolnila povedka) in adjunkte (neobvezna dopolnila povedka), ki ju v svojih opisih uporabljata tudi Miroslav Grepl in Petr Karlík.

Peti sklop obravnava nekatere vrste zvez stavkov (souvěti), ki jih razvršča $\mathrm{v}$ tri glavne skupine glede na razmerja stavkov v stavčni zvezi - kompletacijo (kompletace), determinacijo (determinace) in koordinacijo (koordinace). Kompletacija zadeva odvisnike, ki so v stavčni strukturi nadrednega stavka obvezni, ker nadomeščajo obvezna dopolnila povedka nadrednega stavka. To so večinoma povedkovi, predmetni in redkeje prislovni odvisniki (str. 793-795). Determinacija zadeva prilastkove in večino prislovnih odvisnikov, torej odvisnikov, ki natančneje določajo lastnosti samostalnika ali glagola, vendar niso njegovo obvezno dopolnilo. To pomeni, da Akademska slovnica opušča tradicionalno primarno delitev na priredje (paratakso) in podredje (hipotakso), čeprav uporablja tudi ta način opisa medsebojnih razmerij stavkov. Poglavje o determinaciji (Souvětná determinace, str. 813-853) je pregledno razdeljeno in obravnava posamezne vrste odvisnikov skupaj z možnimi vezniki, njihovo sinonimijo in tudi številnimi praktičnimi primeri.

Zadnji, šesti sklop, namenjen besedilni skladnji, obravnava izbrane pojave s področja semantike in pragmatike besedila (str. 891-904), povezanost besedila (str. 905-917) ter členitev in načela tvorbe besedila (str. 18-938).

Nova Akademska slovnica knjižne češčine torej prinaša nekatere teoretičnometodološke in terminološke novosti v primerjavi s podobnimi priročniki. Po drugi strani pa vsebuje tudi sorazmerno veliko primerov pojavov, ki so v sodobnem jeziku pogosti, in se ne izogiba niti bolj pogovornim, celo nekaterim substandardnim jezikovnim sredstvom, ki jih pogosto dopolnjuje s konkretnimi navedki iz korpusa. Slovnica je načeloma zelo pregledno urejena in snov tudi smiselno razdeljena na sklope, poglavja in podpoglavja, vendar manjka bolj podrobno kazalo celote, ki bi bralcu pomagalo ugotoviti, katera snov se obravnava. Na začetku priročnika (str. 7-8) je namreč samo skrajšano kazalo sklopov in njihove strukture v obliki najpomembnejših poglavij. Podrobnejša delitev snovi je prikazana šele na začetku vsakega posameznega poglavja. 